\title{
Between the Frontier of Learning and School Failure in Attention Deficit Hyperactivity Disorder
}

\author{
Elizane Franchi Pelligrini ${ }^{a^{*},}$, Alessandra Cury Nesso ${ }^{b}$, Alessandra Maria Sambrano Zaccaro ${ }^{c}$, \\ Daniela Cristina Calera Berenguel ${ }^{\mathrm{d}}$, Estela Jaime Campos ${ }^{\mathrm{e}}$, Renata Pereira Magalhães \\ Rodrigues $^{\mathrm{f}}$, Vania Maria Dalecio ${ }^{\mathrm{g}}$, Vilma Aparecida Marim Bolssone ${ }^{\mathrm{h}}$, Leonila Santos Almeida \\ Sasso, Valéria André dos Santos ${ }^{\mathrm{j}}$, Júlio César Andrék \\ ${ }^{a}$ School "Maria Educadora”, Itajobi, São Paulo, Brazil \\ ${ }^{b}$ Pedagogical Coordinator of the Municipality of Itajobi, Itajobi, São Paulo, Brazil \\ ${ }^{c}$ Manager of the Educational Hub Favene of Itajobi, Itajobi, São Paulo, Brazil \\ dSchool "Maria Educadora", Itajobi, São Paulo, Brazil \\ ${ }^{e}$ Elementary School Teacher of the Municipality of Santa Adélia, Santa Adélia, São Paulo, Brazil \\ ${ }^{f}$ Elementary School Teacher Municipal network of São José do Rio Preto City Hall, São José do Rio Preto, São \\ Paulo, Brazil \\ ${ }^{g}$ School Director of the Municipal Network in the Department of Education of the Prefecture of Itajobi, Itajobi, \\ São Paulo, Brazil \\ ${ }^{h}$ Elementary School Teacher at Colégio Maria Educadora, Itajobi, São Paulo, Brazil \\ independent Researcher, Mirassol, São Paulo, Brazil \\ ${ }^{j}$ State School "Rui Barbosa”, Glória D’Oeste, Mato Grosso, Brazil \\ ${ }^{K}$ Center for the Study and Development of Health Education-CEDES, Medical School of Medicine of São José \\ do Rio Preto - FAMERP, Brazil
}

*Corresponding Author: Elizane Franchi Pelligrini, School "Maria Educadora”, Itajobi, São Paulo, Brazil

\begin{abstract}
The schooling of children with Attention Deficit Hyperactivity Disorder (ADHD) is still a great challenge, since in addition to the difficulties in responding to academic demands in terms of learning, the pattern of social interactions, with colleagues and teachers, also imposes obstacles to effective participation in all activities in the school environment. Raising factors that lead children with ADHD to not learn at school was the aim of this longitudinal retrospective study of the historical cohort type that used the review of 49 medical records, with 3 units of analysis: personal and socioeconomic data, educational training data and specific data containing dichotomous questions with a single answer. The little explored data yet shown here, for patients with ADHD in the sample, are: $4.1 \%$ of history of adoption, $2 \%$ of existence of underlying pathology, 22.4\% of history of drug addiction for the father and 10,2\% for the mother. Disagreeing data from the literature: $87.7 \%$ of non-failure. It is essential to constantly seek to know more about this disorder, both on the part of education professionals and the family, from diagnosis to treatment, in order to contribute to offer, in the school context, a meaningful teaching for patients with ADHD.
\end{abstract}

Key terms: ADHD, Elementary school, Sociodemographic factors, Family history.

\section{INTRODUCTION}

Attention Deficit Hyperactivity Disorder (ADHD) is a mental disorder that presents as main manifestations inattention, impulsivity, difficulty concentrating and hyperactivity according to the Diagnostic and Statistical Manual of Mental Diseases - 5th Edition (DSM-V) [1]. It is a psychiatric disorder of great importance in public health, considering the problems caused both in childhood, adolescence and at school; whether in adulthood and at work; or both, and in relationships with others.

It is estimated that around 5 to $8 \%$ of the world's child population and $2.5 \%$ in adults have this disorder $[1,2]$. 
The lack of diagnosis and appropriate treatment causes great damage to the life of the child and the adult, in the professional, social, personal and emotional aspects. Without treatment, other disturbances can be associated with the condition, self-esteem is increasingly compromised, and the individual can isolate himself from the world.

\section{ATTENTION DEFICIT HYPERACTIVITY DiSORDER (ADHD)}

ADHD was first described in 1902 by the English pediatrician George Still, who observed changes in behavior in children. He believed that the factor was not attributed to educational problems, but to biological determinants. The disorder has been studied in several countries and since 1960 it has received different names [3].

Epidemiological studies have shown associations between ADHD and various environmental factors. These mainly include pre- and perinatal risk factors (maternal stress, smoking or alcohol consumption during pregnancy, low birth weight, prematurity), environmental toxins (organophosphates, polychlorinated biphenyls, lead), unfavorable psychosocial conditions (severe deprivation of early childhood, maternal hostility) and dietary factors [4,5].

ADHD is a mental health disorder and has three basic characteristics: inattention, hyperactivity and impulsivity. This disorder has a great impact on the life of the child or adolescent and the people with whom they live (friends, parents and teachers). It can lead to emotional difficulties, family and social relationships, as well as poor school performance [6].

According to DSM-V [1], ADHD is defined by 18 symptoms that make up two dimensions: inattention and hyperactivity/impulsivity. Individuals with proven ADHD are considered to have the main symptoms such as inattention and hyperactivity/impulsivity for a period of six months or more.

The hyperactive child often feels isolated and separated from peers but does not understand why he/she is so different. He/she is disturbed by his/her own disabilities. Without being able to complete a child's normal tasks at school or at home, the hyperactive child may suffer from stress, sadness and low self-esteem [1].

\subsection{School Performance in ADHD}

In both children and adolescents, ADHD is directly related to poor academic performance and academic unaccomplishment, social rejection and high levels of interpersonal conflicts. Children with ADHD are significantly more likely to develop conduct disorder in adolescence and antisocial personality disorder as adults, thus increasing the chances of developing substance use and prison disorders [1].

According to a research by Goldstein [7], it is concluded that about 20 to $30 \%$ of children with ADHD may have problems of inattention without significant problems of over activity or impulsivity and that such children are more likely to develop depression anxiety, disruptive behavior and poorer school performance, with greater learning difficulties.

In the learning of students diagnosed with ADHD, it is essential to understand what level of operation they are in, for their activities to be adjusted according to their performance. These students need to be stimulated with fun games, playful games and rule games, which help the student to socialize and to know how to lose and win. These students are very disorganized, they need to have someone to help them organize better. This is up to the professional in the field and family members, to give them more time to adjust to their activities. Knowing how to understand the learning process of these students is particularly important [3].

\subsection{The Teacher before ADHD}

Few teachers are aware of ADHD and often have a misperception about the disorder.

As the teacher is the mediator of knowledge, he must understand exactly his educational responsibility in the life of the student with ADHD. According to the Brazilian Association of Attention Deficit (BAAD):

\footnotetext{
"The teacher is one of the great observers of children, he/she is the one who knows them as few, because he/she manages to maintain his individual view, even in the midst of a 'crowd'. Unlike other professionals, he/she is one of the few who sees children and adolescents in their routine, in the reality in which they are inserted. " [8]
} 
Teachers must know about ADHD, be resourceful and flexible to help the student with ADHD. Information is the most important step in understanding how these children's heads work. It is not up to the teacher to diagnose ADHD, but if he/she perceives characteristic symptoms in any student, he/she should guide the family to seek for help. The sooner medical and psychotherapeutic treatment is chosen, the less difficulties he/she will have in his/her school life, which will be reflected in adult life [9].

However, practice has shown that the educational system is still quite stratified, and teachers find it difficult, sometimes unsurpassed, to make the adaptations that are necessary to assist the student with ADHD. The teacher must first understand that the student is not a problem, but that he has a problem; which is not the result of a lack of education and/or an intellectual "deficit", but which compromises both conduct and academic performance. The most important thing is that the teacher allows himself to be intrigued, curious, that he sees this student as an opportunity to learn, as "reading" a student should be a passion in permanent construction for the teacher [10].

\subsection{Family, School and the Child with ADHD}

Parents should have knowledge about ADHD, the acceptance of the problem influences the quality of the investments that parents will make in helping and facilitating their children's lives. It is essential that parents accept their children's difficulties so that they can assume and fulfill the challenging role in the child's progress [11].

Studies indicate a high level of stress for parents in monitoring children aged three to six. It seems to decrease later, but it is always greater when compared to parents of control children. In addition, the stress of those parents is even greater when there is a comorbidity with challenging opposition disorder. Studies carried out with the parents of these children indicate that they feel more dissatisfied with their parental roles. Mothers have an increased vulnerability to depression and there is greater family consumption of alcohol due to stress [12].

School and family working cooperatively increase the likelihood of a child having a successful school life experience. The child with ADHD has difficulties which parents and the school need to work together for this student to achieve success. We can understand that when Cavalcante states "The collaboration between parents and school improves the school environment and transforms the students' educational experience into a more meaningful experience" [13].

It is important to have a communication from parents with the school coordination to understand how the institution deals with students with ADHD, and whether teachers have specific guidelines to assist the learning process of children who have attention deficit and hyperactivity. When the child receives support, he/she is able to develop his/her activities, even with his/her limitations [3].

For Cunha [14], frequent communication between the school and the family is an important factor to guarantee this relationship, so that both teachers and parents can exchange relevant experiences during difficult times. Knowing what is happening during the time that the child is in the other environment helps to make up the real picture of the situation, and that trusting the other is what really establishes the partnership.

\section{Purpose of the Present Study}

The present study aims to raise factors that lead children with ADHD to not learn at school.

\subsection{Methodology}

This is a longitudinal retrospective study of the historical cohort type, which uses the review of medical records kept in files, and this research was approved by the Ethics and Research Committee CEP of Faculdades Integradas Padre Albino - FAMECA under OPINION CONSUBSTANCED OF CEP No. 3.486.315.

\subsection{Sample}

The sample universe of the research was composed of a total of 100 multidisciplinary medical records of students from the Municipal School of Elementary Education "Faride Aborihan", from the city of Marapoama, state of São Paulo, Brazil, from the years 2017 to June 2019. The medical records were allocated in the Archive Service of that school and they contain assistance information for students who were diagnosed with ADHD and were attended by a multidisciplinary team. 


\subsection{Variables}

The variables were defined according to the personal and socioeconomic data provided for in the first part of the data collection, being composed of continuous variables and discrete variables. The remaining of the specific variables were defined according to the data found in the medical records.

The independent variables were: gender, age, ethnicity, parents' marital status, family income, place of residence and with whom they live with.

The dependent variables were: whether parents have a history/situation of drug addiction, history of domestic violence, school failures (if so, how many, the grades in which failures occurred, in which subjects, whether parents were aware of all school failures), regular grade in which he is currently enrolled, if he has always studied at the same school, if there were school expulsions, observable behaviors in school routine, beginning of ADHD signs and symptoms (school year), subjects that present greater difficulty, student's academic performance and confirmed medical diagnosis of ADHD.

\subsection{Design}

The medical records were analyzed individually one by one and for the registration and organization of data. The units of analysis were separated and divided into three parts: personal and socioeconomic data, educational background data and specific data containing the answers to the single answer dichotomous questions.

The unit of analysis used was the object of the absolute and comparative strategy assessment. The descriptive analysis included absolute and relative frequency for categorical variables, tables and graphs using the IBM-SPSS Statistics version 24 software (IBM Corporation, NY, USA) for statistical treatment.

\section{Results}

\subsection{Final Sample Size}

In this study, it was initially proposed to investigate 100 medical records, however 51 medical records did not have conditions for inclusion in the research due to lack of filling in correct data, medical records that were incomplete or lacking consistent data and other medical records that did not meet the research requirements. Thus, out of 100 medical records, only 49 (49\%) medical records were included in this research.

\subsection{Independent Variables}

Of the 49 medical records surveyed, $31(63.2 \%)$ were male children and $18(36.7 \%)$ were female. Thus, in this research it was evident that more male children were diagnosed with ADHD.

As for the age of children who have been diagnosed with ADHD and attended to, there is a huge variety and range of ages, with the oldest being 17 years old, and the youngest in the age group of 6 years.

Regarding ethnicity, the vast majority of children 36 (73.4\%) were white, and only 13 (26.5\%) were brown skinned and there was no presence of black, Indian or Japanese children.

Regarding the number of siblings, the data are shown in Graph 1.

Graph 1: Number of siblings $(n=49,2019)$

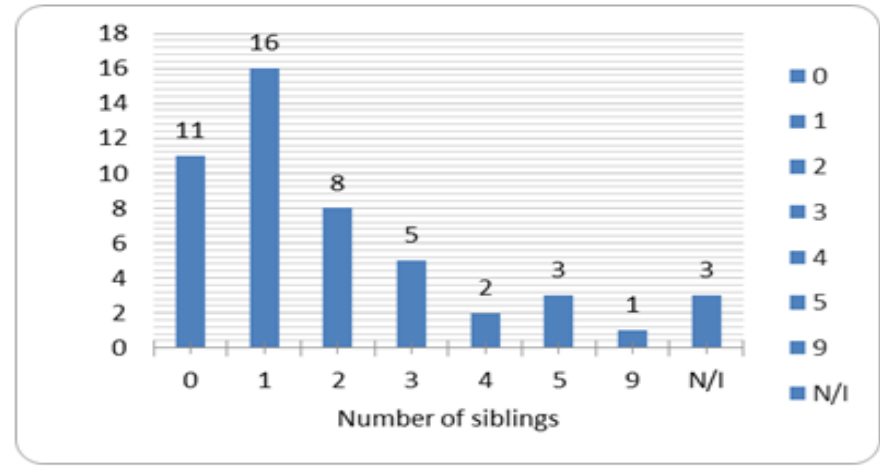


We also sought to find out if some children in this research were adopted, and it was found that 47 (95.9\%) are biological children and only $2(4.08 \%)$ have a history of adoption.

Regarding the existence of a basic pathology, it was found that in 48 (98\%) medical records there was no basic pathology and only one child had a confirmed diagnosis of Fetal Alcohol Syndrome (ICD Q86.0).

Regarding the parents' marital status, 28 (57.1\%) are married and 21 (42.8\%) are separated.

In order to identify who are current guardian for the minor and with whom he/she resides, the research identified that there is a great plurality as can be seen in the graph 2 .

Graph 2: Current guardian for the minor and with whom he/she resides $(n=49,2019)$

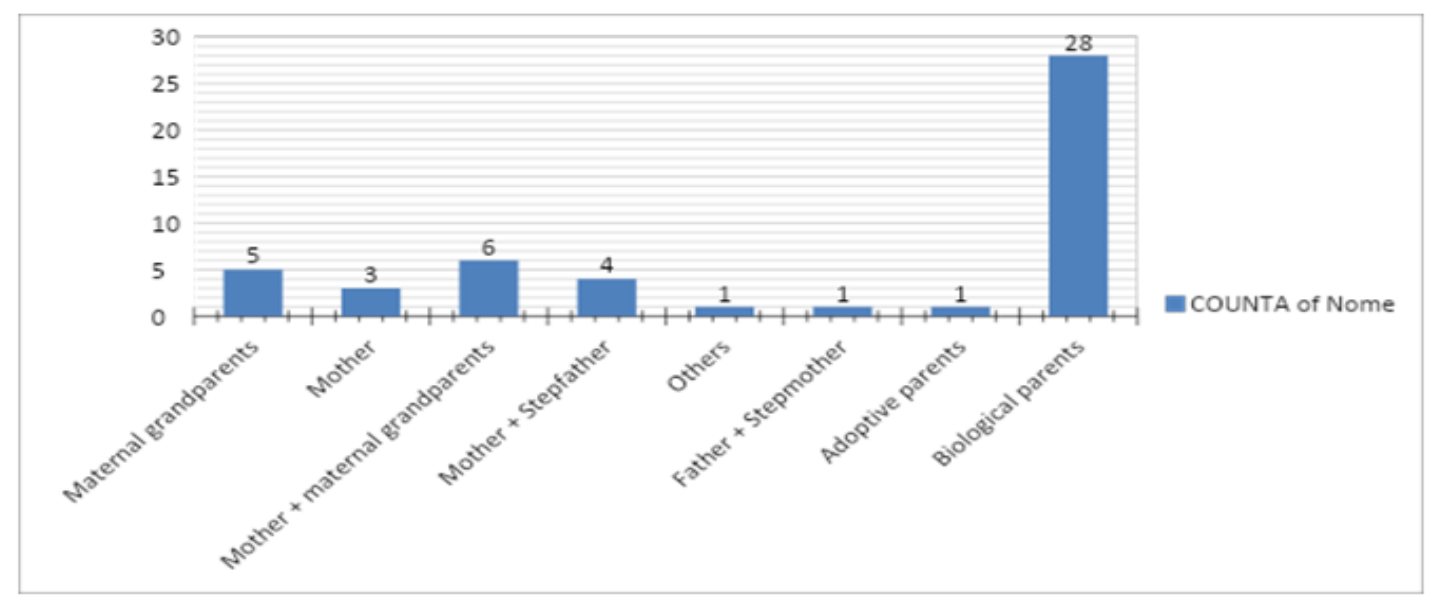

Regarding if there are parents in prison, $45(91.8 \%)$ of the parents are not in prison, $4(8.2 \%)$ are, the theft being the reason for the confinement.

When raising the father's history and drug addiction situation, it was found that 35 (71.4\%) of the fathers do not have a history of drug addiction and 11 (22.4\%) of the fathers have a history of drug addiction. According to what was found in the survey, fathers involved with drug addiction have been so since adolescence, the most prevalent type of drug being alcohol.

Regarding the involvement of the mother in a drug addiction situation, it was found that $41(83.6 \%)$ do not have a history of drug addiction, $5(10.2 \%)$ have been involved with drug addiction since childhood or adolescence. As for the most prevalent type of drugs among mothers, the results are shown in Graph 3.

Graph 3: Types of drugs prevalent among mothers $(n=49,2019)$

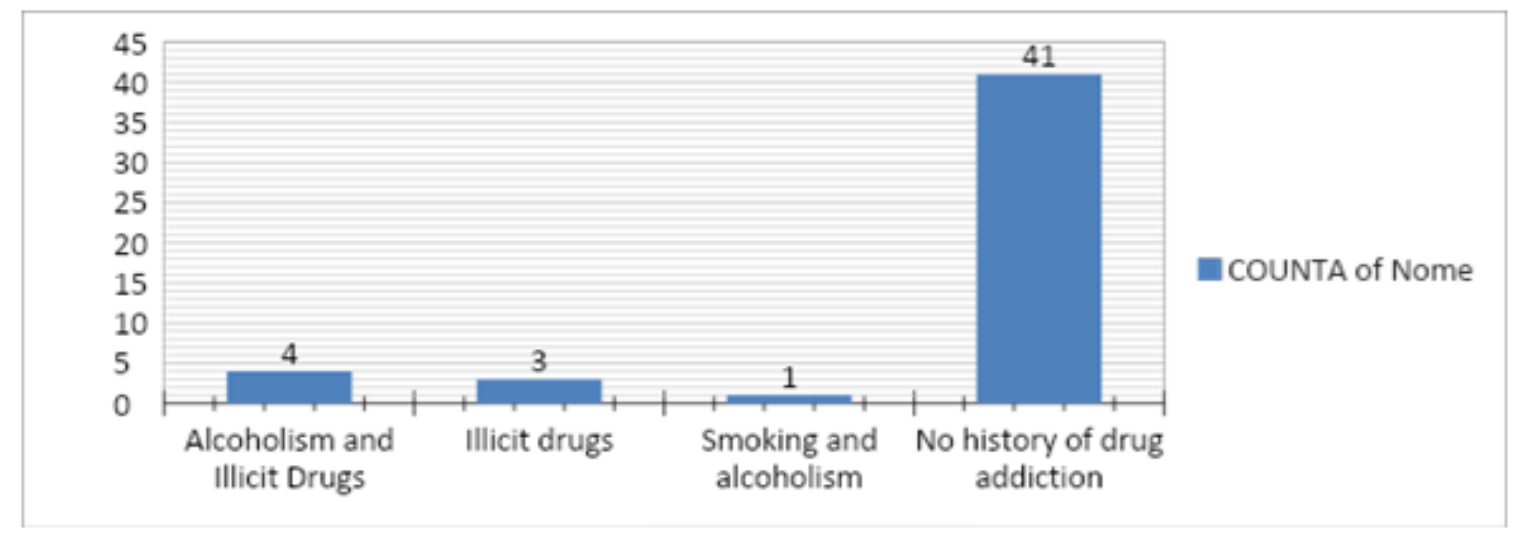

In the investigation of the history of domestic violence, it was found that in 40 (81.6\%) there are no reports of domestic violence, however in $9(18.3 \%)$ there are reports of domestic violence in homes where children have ADHD.

Of the 49 medical records investigated for children with ADHD, $12(24.4 \%)$ live in rural areas and 37 $(75.5 \%)$ in urban areas. In this research it was found that $49(100 \%)$ of residential homes have a family income of 1 to 3 minimum wages. 
Despite the children's history of ADHD, it was found that $43(87.7 \%)$ of them never failed and only 6 $(12.2 \%)$ had a history of failing. Of the $6(12.2 \%)$ children who failed 4 failed 1 year and 2 failed 2 years. The grades in which the failures occurred can be seen in Graph 4. Regarding the question whether the parents were aware of their children's failure, 6 (100\%) were.

Graph 4: Grades in which failures occurred $(n=49,2019)$

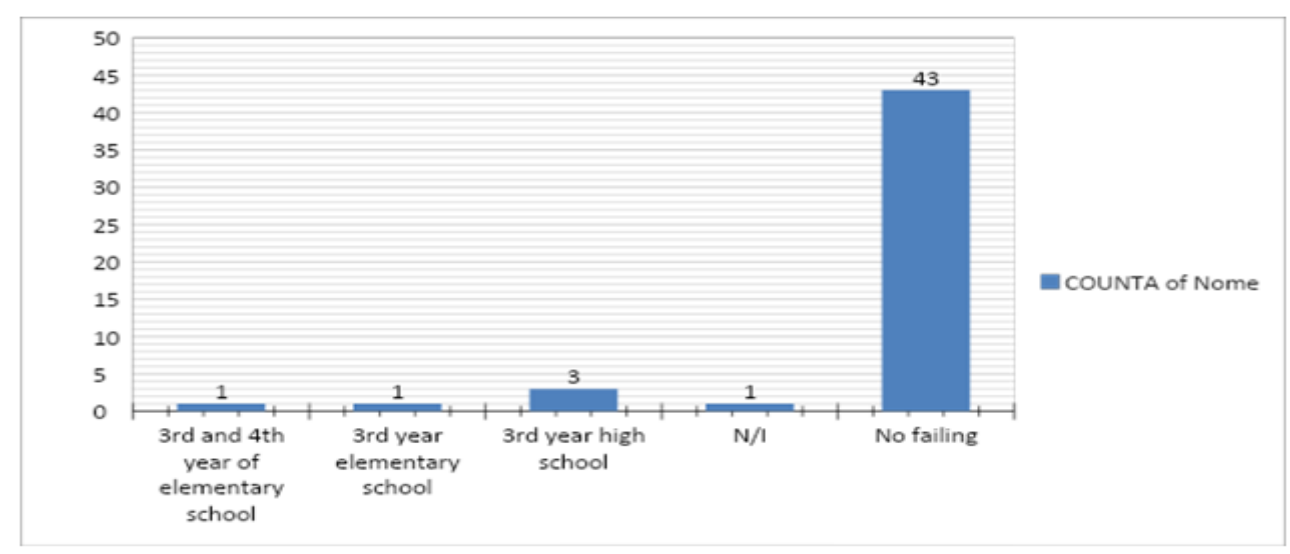

The failures occurred due to three basic reasons: 2 for excessive absences, 2 in two main subjects (Portuguese and Mathematics) and 1 presented a poor performance in all subjects, which culminated in failure.

At the time of data collection, the 49-year-old students surveyed with ADHD were distributed in several grades of elementary school I and II as shown in table 1.

Table 1: Grades in which students with ADHD are enrolled $(n=49,2019)$

\begin{tabular}{|l|l|l|l|}
\hline Elementary School & $n$ & High school \\
\hline Grade & 2 & Grade & $n$ \\
\hline 1st & 6 & 1st & 1 \\
\hline 2nd & 9 & 2nd & 2 \\
\hline 3rd & 5 & $3 \mathrm{rd}$ & 5 \\
\hline 4th & 7 & & \\
\hline 5th & 3 & & \\
\hline 6th & 7 & & \\
\hline 7th & 1 & & \\
\hline 8th & 1 & & \\
\hline 9th & & & \\
\hline
\end{tabular}

When assessing whether those included in the survey always studied at the same school, $30(61.2 \%)$ always studied at the same school, while 19 (38.7\%) came from other schools. The students of this research, although they have ADHD, were never expelled from any school they attended as verified in the researched medical records.

The data regarding general school performance and in which subjects are more difficult can be seen in graphs 5 and 6.

Graph 5: Overall school performance of students with ADHD $(n=49,2019)$

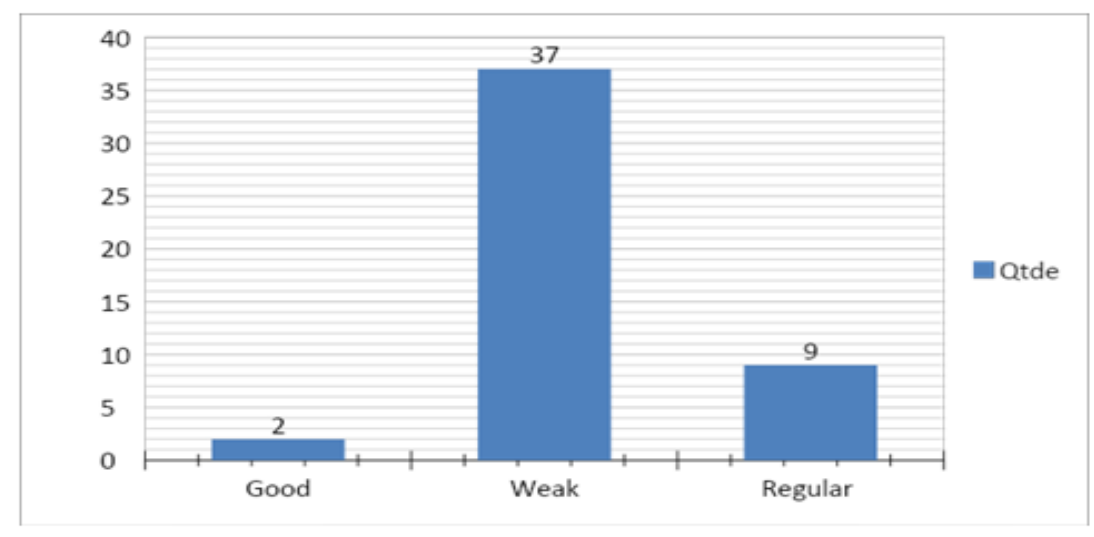


Graph 6: Main subjects that students with ADHD have greater difficulty $(n=49,2019)$

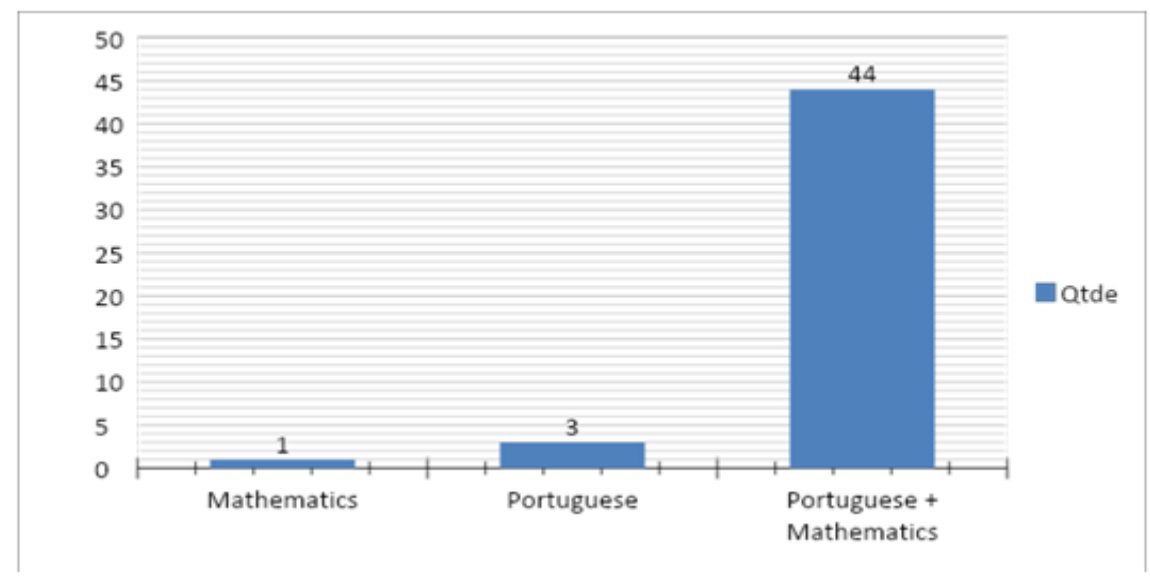

The time lapse between the medical diagnosis of ADHD and the collection of data in medical records is shown in Graph 7.

Graph 7: Time lapse (in months) between medical diagnosis of ADHD and data collection from medical records $(n=49,2019)$

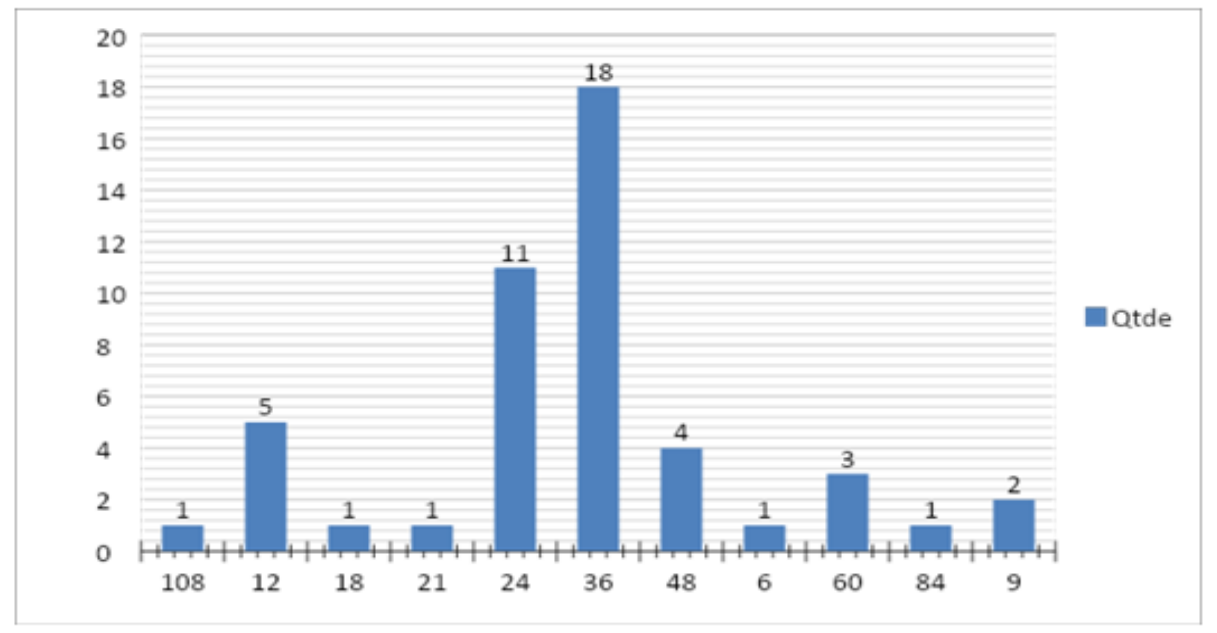

\subsection{Dependent Variables}

Data on observable daily school behaviors specifically related to ADHD signs and symptoms and diagnostic criteria (DSM-5, 2014) in the children surveyed can be seen in graphs 8 to 11 .

Graph 8: Frequency of observable daily school behaviors, related to ADHD signs and symptoms and diagnostic criteria - Inattention criteria $(n=49,2019)$

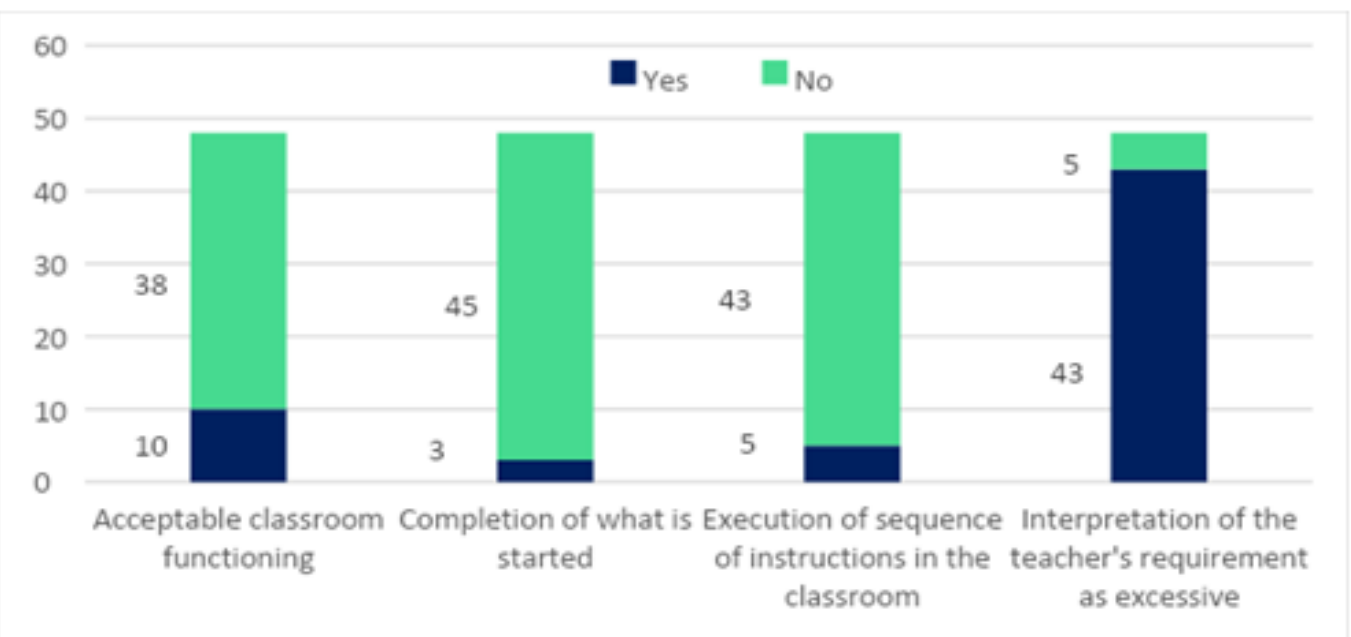


Graph 9: Frequency of observable daily school behaviors, related to ADHD signs and symptoms and diagnostic criteria - Criteria for hyperactivity and impulsivity $(n=49,2019)$

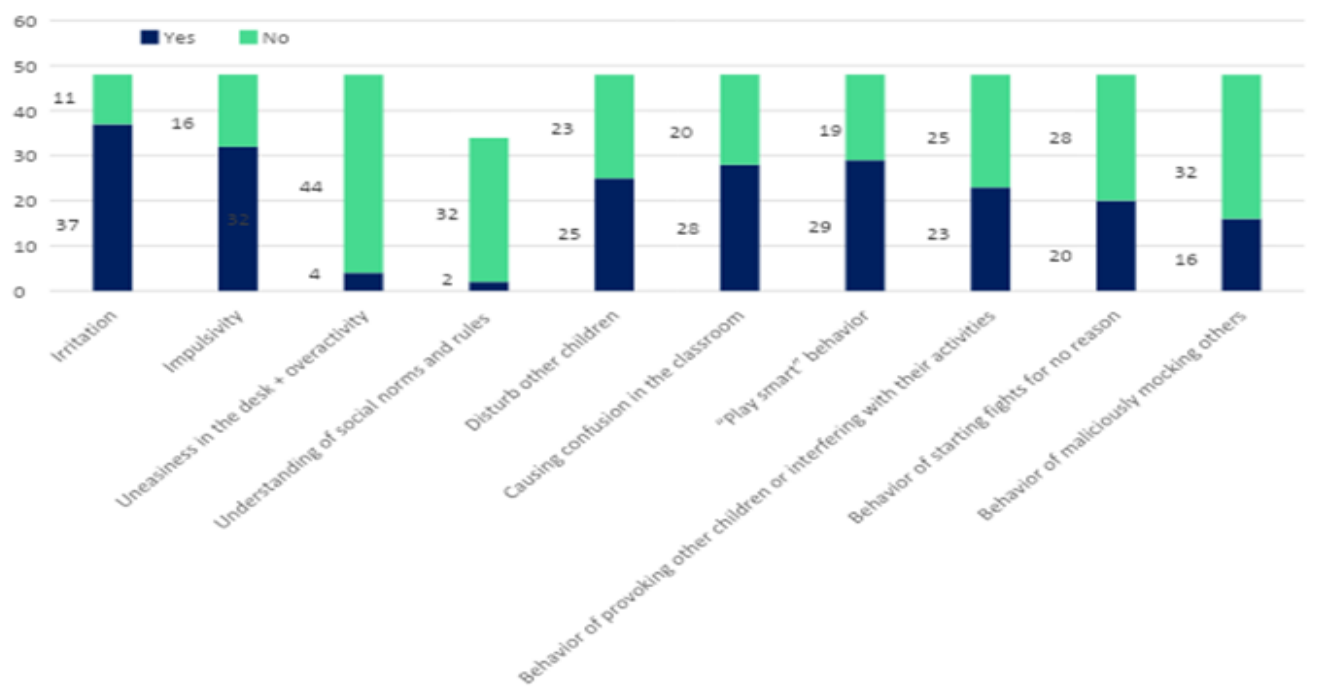

Graph 10: Frequency of observable daily school behaviors, related to ADHD signs and symptoms, showing damage in social functioning $(n=49,2019)$

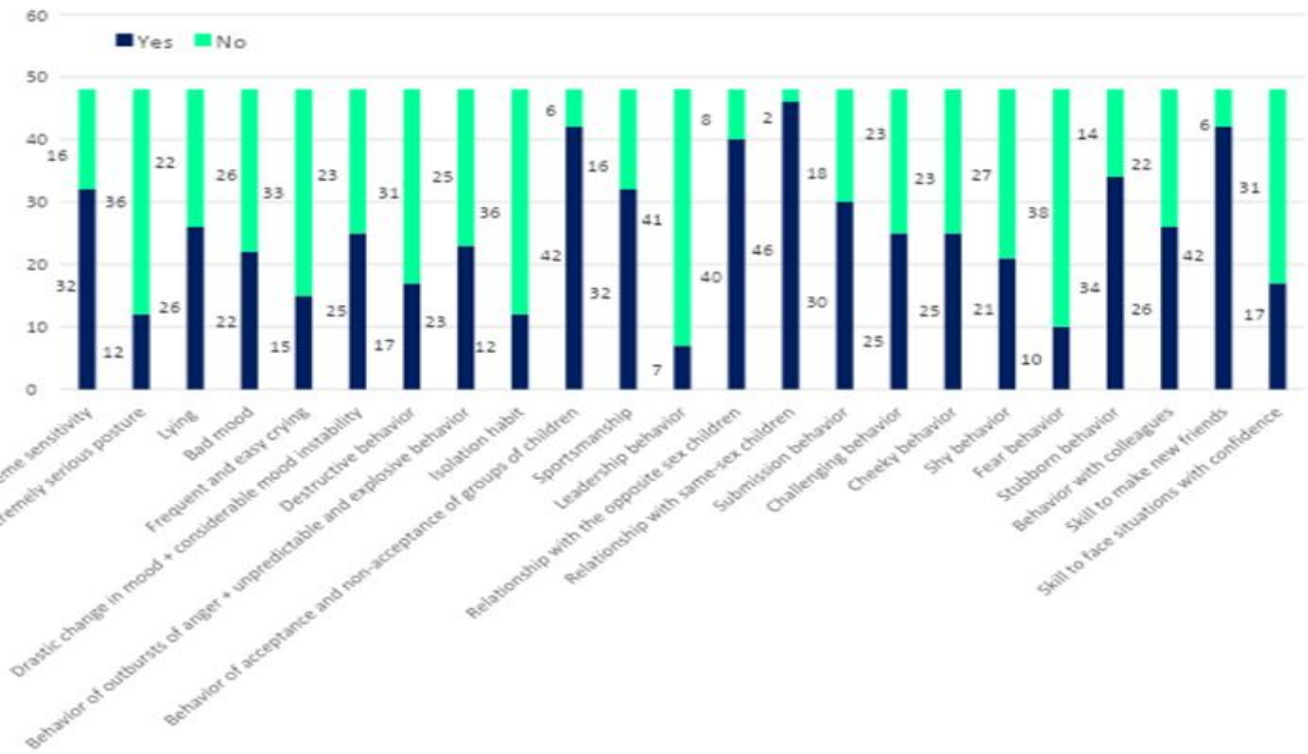

Graph 11: Frequency of observable daily school behaviors, related to ADHD signs and symptoms, showing damage in school functioning $(n=49,2019)$

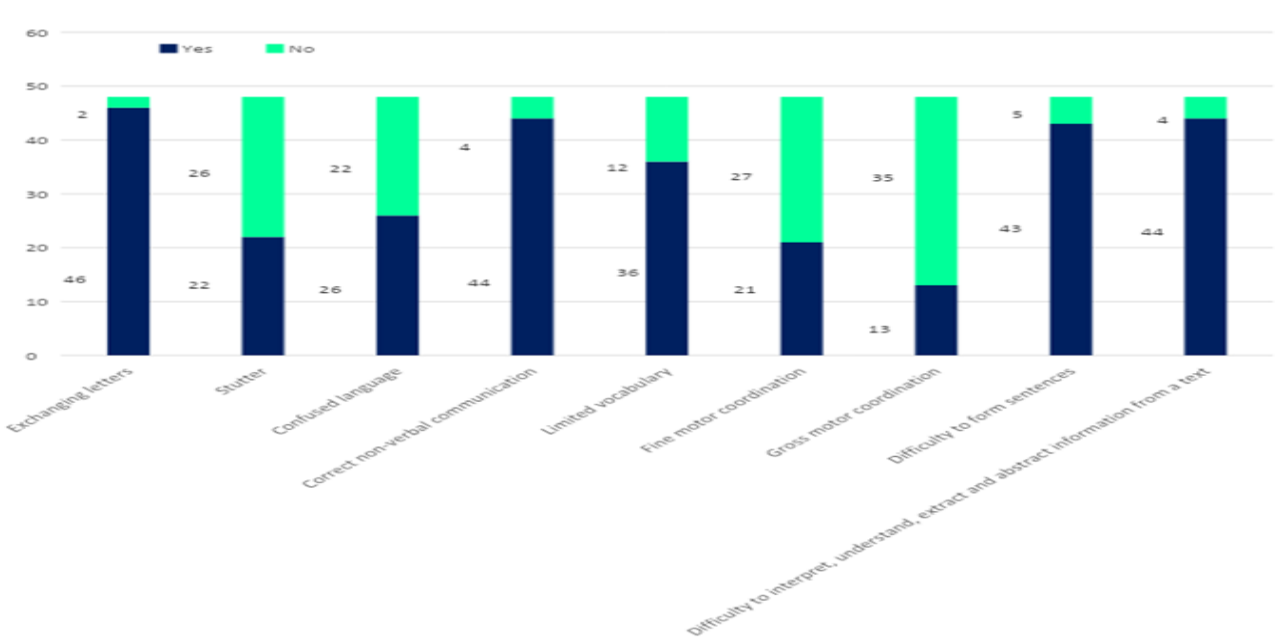




\section{DISCUSSION}

Research shows that the prevalence of ADHD is higher among boys than among girls, with a ratio of 2:1 in population samples and 9:1 in clinical samples [15], data corroborated in the present study. One of the justifications presented for this fact is based on the psychosocial profile of the girls, who are generally inattentive and have no other symptoms, being less uncomfortable for the family and the school, resulting in a lower number of referrals for treatment [16], Exclude: 2009). In addition, the greater proportion of the disorder in male individuals may be related to the greater number of referrals by boys due to the attribution of hyperactivity to their typical behavior [17].

According to the American Psychiatric Association [1], ADHD, considered a neurodevelopmental disorder, appears before the age of seven.

The fact that ADHD patients are diagnosed mainly during the school period is related to the greater evidence of the signs during the children's entry into school activities, due to from that moment the relationship difficulties with teachers and colleagues become evident, since in the school period the child expands his social system - from the family nucleus to the school and starts to relate with colleagues and teachers [18].

The etiological factors of this pathology are still unknown; however, it is supposed to have a neurological basis, being strongly influenced by the psychic condition and the patient's family context. Many studies show that, despite not being the cause of the development of ADHD, in children with neurobiological predisposition, exposure to a troubled family context acts as a risk factor that can trigger the manifestation of symptoms and alter the course of the disorder $[17,18]$. In Brazil, a study has revealed that children exposed to constant marital confrontation are 11.66 times more likely to be diagnosed with the disorder [20].

Also according to the line of thought of Rohde \& Benczik [21], a very permissive parenting style can be a consequence and not a cause of the disorder, family characteristics such as: chaotic family functioning, high degree of marital conflict; low maternal education; families with lower socioeconomic status; families with only one parent or guardian, or that the father leaves the family, elements found in the present investigation.

Other literature data also show a relationship in family dysfunction and in ADHD, where dys functionality in family dynamics at home is associated with the presence of symptoms of the disturbance [22], corroborated by the present study. With regard to religiosity, data not raised in this research, students who report not having any religion have greater family dysfunction than Christian students and students who do not have religion have greater attention difficulties in relation to Catholics [22].

The literature reports up to 3 times greater chances of failure [23] given that this is not consistent with those found here (6 cases of failure, 12.2\%), but we reiterate the question of continued progression existing in our system educational policy.

With regard to the lower school performance of the child with ADHD when compared to the child without ADHD, it is emphasized that the practical-productive performance involved in the act of reading and writing, may be compromised with neurofunctional changes in the brain regions responsible for entry, processing and execution of information, which can affect children with ADHD [24]. These children have little persistence of effort for tasks and low sustained attention, which justifies our data on the predominance of poor school performance $(37,75.5 \%)$. However, this problem usually arises when it is attributed to boring, tedious, prolonged or repetitive activities that have no intrinsic appeal to him [25].

However, Oliveira et al. [17] showed in their sample that intrinsic motivation and total motivation were not related to school performance.

Pastura et al. [23] by stating that the need for $50 \%$ of children diagnosed with ADHD to take tutoring in reading and arithmetic, endorse our results that 44 children (89.8\%) have more difficulty in Portuguese and Mathematics. It is important to highlight that factors such as lack of attention and motor delays present in children with learning difficulties may be associated with unaccomplishment in school activities [26]. Each time a new motor gesture is learned, it activates brain areas responsible for attention and reasoning, stimulating several brain areas responsible for primarily cognitive learning, such as reading, writing and arithmetic. [27] 
Children with ADHD have difficulties in modulating and self-regulating their levels of intrinsic motivation, indicating a primary dysfunction of the reward system that implies the greater need for positive reinforcement by the mediator or teacher to perform school tasks and there is a relationship between extrinsic motivation and performance in reading, writing and arithmetic tasks [17].

Also, according to the American Psychiatric Association [1], ADHD has three main symptoms: inattention, hyperactivity and impulsivity.

Individuals with ADHD experience great difficulty in staying engaged in tasks which have no immediate reward and have a high degree of aversion to delay [28]. Even with the possibility of obtaining more significant rewards in the future, they tend not to be able to self-regulate their behavior and end up preferring immediate rewards, even when they are smaller. Barkley [29] and Montiel et al. [30] refer such behaviors to damages in executive functions, specifically in inhibitory control, which is the ability to control a strong impulse in favor of behavior that is more appropriate to the situation (Diamond \& Lee, 2015). The aforementioned behavioral characteristics in combination with the attentional deficits common to ADHD are the main causes of damages in the learning process [31] by promoting the inattention observed through everyday school behavior such as not functioning in the classroom, the non-completion of the tasks initiated and the failure to execute sequences of instructions in the classroom, considering the demands of the teacher to be excessive.

The resistance to remain seated and quiet during situations in which the child is expected to remain that way clearly demonstrates hyperactivity and the difficulty in waiting for his/her turn, interrupting people and speaking in a hasty way, the impulsiveness.

Tonelotto and Gonçalves [32] showed that children with attention problems, when compared to the group without the same problems, had a more negative perception of their performance in the classroom context, perceived teachers as less sympathetic towards them and were more cited by their colleagues as rejected and, in the same proportion, less cited when the question was acceptance. Likewise, the study by Capelatto et al. [33] identified that children with ADHD feel more guilty, believe that they do more wrong things and have negative self-esteem. For the authors, the difficulties in the attention and executive functions negatively affect the performances in schoolwork and daily tasks, which in turn, can impact the development of self-esteem and cause more feelings of guilt. These 2 studies were carried out with Brazilian children. Molina and Maglio [34] working with Argentine children in the same age group, showed the same trend as in Brazilian studies, with the most negative self-perception being reported by children with ADHD when assessing their academic competence, social acceptance, behavior and global self-esteem . These same children also showed a positive bias, when compared to the parents' perception, in the domains of academic, social and behavioral competence.

All of this reiterates that children with ADHD have difficulties in learning and social interaction with their peers, directly influencing their school performance $[23,35]$. For positive changes to occur, activities need to be interesting and stimulating to all students, especially students who have attention difficulties and low engagement in the proposed activity. The teacher needs to be clear in his explanations, being able to use images and writing as an aid, it is essential to verify the student's real understanding in the activity [36]. These activities must be playful, as they are indispensable to the educational practice, contributing and enriching the intellectual development of children [37].

Data in the literature show that the low performance in the motor action of the child with ADHD [38] reinforces the characteristics of the disorder emphasized by scholars in the area [39-43]. Children with ADHD have a constant alternation of tasks, reluctance to engage in complex activities that require organization and rules, tolerance to waiting, difficulties in controlling their impulsiveness and staying focused on the task, needing immediate reward. Thus, possibly the fact that the child with ADHD needs to wait his/her turn to participate in the activities, as well as have diversified materials in the same task, contributes to the dispersion. The delays in motor performance, which reinforce the need for activity modification, also favor that he/she gets involved in confusion and transits around other spaces in the classroom. Attention problems can influence basic motor skills (fine and gross stabilizer, locomotive and manipulative) $[38,44]$. Students with ADHD have a tendency to give quick, although inaccurate answers [39], as well as difficulties with the spatial organization, alignment and maintenance of body posture [45], and this difficulty in maintaining posture can be a determining factor in the ability to maintain attention in activities. The attitudes of engagement demonstrate that the child with ADHD performs most of the skills with difficulties to concentrate, consequently reflecting on the delay of his/her performance in the skills proposed during the class. [38] 
With regard to social interactions, most of them have difficulties to carry out school activities in groups and to participate in the games and difficulties to make friends outside the school environment, which implies a restricted number of friends and social isolation, which can be seen in their reports of friends rejection when they want to play together, and the desire to have more friends and to be accepted. In the social interactions with adults, it is reported that they are also permeated by more aversive than positive interactions, with most of the children reporting being targets of scolding and cursing. [46]

\subsection{Implications for Practice}

It is important to emphasize that children learn in an integrated way, the movement experiences of any activity, must make connection with other areas of knowledge, such as associative, deductive and abstract thinking for the learning of reading, written language, mathematics, among others. In this sense, the importance of teachers' pedagogical reflection is emphasized, redimensioning the role of the educator and placing the learner, especially when he has difficulties in attention and learning, at the center of the teaching-learning process. For this process to occur, it is essential that each teacher uses different methodological proposals, opting for those that best fit the needs of the learners, the school context and the convictions of the educator himself [38].

Low school performance has been strongly associated with the presentation of lower levels of intrinsic motivation [47-49]. Low levels of intrinsic motivation may imply a greater need for external rewards, especially when performing tasks which require greater cognitive effort, as is the case with school tasks. Thus, this result can help to think about management strategies for children with ADHD in the classroom, such as, for example, the positive reinforcement by the teacher [50] since the lower the performance in reading, writing and arithmetic tasks is, the higher the rate of extrinsic motivation [17].

Difficulties in the classroom are challenges encountered by the school with several students and it is necessary to seek to overcome these challenges through strategies that aim to meet the needs of each one, with an emphasis on learning, including those diagnosed with ADHD [51].

\section{CONClusion}

Considering that ADHD is a disorder that affects the student, causes learning difficulties, generates insecurity and anxiety, it is possible to blame this disorder for the behaviors presented by students in cognitive and intellectual development, the difficulties in the teaching-learning process in the classroom can be overcome when the teacher proposes to confront his own knowledge, actions and practices with new knowledge and strategies, aiming at quality teaching and that the way of teaching a student with ADHD proves to be complex and difficult, it is important to realize the potential that this student may or may not develop and that someone has the ability to recognize his responsibility for the result. Therefore, the teacher must have an emotional balance, be creative, and properly know the student's disorder, as this will make it easier for these students to participate in the classroom, and this is what the present investigation presents: data that show how one can properly know the student's disorder, obtained within the school context, since it is up to the school to provide students with $\mathrm{ADHD}$, meaningful learning according to their potential, trying to guarantee everyone a quality education, in an inclusive way.

It is essential to constantly seek to know more about this disorder, both on the part of the education professionals and the family, from diagnosis to treatment, in order to contribute to offer, in the school context, a meaningful teaching for ADHD.

\section{REFERENCES}

[1] Associação Americana de Psiquiatria. Manual Diagnóstico e Estatístico de Transtornos Mentais- DSM-5, $5^{\mathrm{a}}$ ed. Porto Alegre, Brasil: Artmed, 2014.

[2] Polanczyk G.V., Willcutt E. G., Salum G.A., Kieling C., and Rohde L. A., ADHD prevalence estimates across three decades: an updated systematic review and meta-regression analysis. Int. J. Epidemiol. 43 (2), 434-442 (2014). https://doi.org.10.1093/ije/ dyt261

[3] Silva, B. K. M., Família e a escola na aprendizagem da criança com TDAH: a necessidade de uma parceria ativa e produtiva. Pedagogia em Ação, 8(1), (2016). Retrieved November 18, 2020, from http://periodicos. pucminas.br/index.php/pedagogiacao/article/ view/11042

[4] Faraone S. V., Asherso, P., Banaschewsk, T., Biederma, J., Buitelaar J. K., Ramos-Quiroga J. A., Rohde L. A., Sonuga-Barke E. J. S., Tannock R., and Franke B., Attention-deficit/hyperactivity disorder. Nat. Rev. Dis. Primers. 1:15020 (2015). https:// doi.org.10.1038/nrdp.2015.20 
[5] Thapar A, and Cooper M., Attention deficit hyperactivity disorder. Lancet. 387(10024), 1240-1250 (2016). https://doi.org.10.1016/S0140-6736 (15)00238-X

[6] Rohde L. A. P., and Benczik E. B. P., Transtorno de Déficit de Atenção: O que é? Como ajudar? Porto Alegre, Brasil: Artmed, 2009.

[7] Goldstein S., and Goldstein, M. Hiperatividade: Como desenvolver a capacidade de atenção da criança, $13^{\mathrm{a}}$ ed. Campinas, Brasil: Papirus, 2009.

[8] ABDA - Associação Brasileira do Déficit de Atenção (2017, June 20). Relação professor, escola, aluno e família. A educação unida para o sucesso! Retrieved November 18, 2020, from https://tdah.org.br/relacaoprofessor-escola-aluno-e-familia-a-educacao-unid a- para-o-sucesso/

[9] Silva A. B. B., Mentes Inquietas TDAH: Desatenção, Hiperatividade e Impulsividade. Rio de Janeiro, Brasil: Objetiva, 2009.

[10] Rohde L. A. P., and Mattos P. Princípios e práticas em transtornos de déficit de atenção/hiperatividade. Porto Alegre, Brasil: Artmed, 2003.

[11] Araújo F. L. C., Transtorno de Defícit de Atenção e Hiperatividade - TDAH, Monograph in Specialist in Institutional and Clinical Psychopedagogy, Universidade Estadual Vale do Acaraú, Sobral, Ceará. Brasil. Pp. 16 (2008). Retrieved November 18, 2020, from http://www.educadores.diaadia.pr.gov.br/arquivos/ File/2010/artigos_teses/Pedagogia/transtorno_de_deficit_de_atencao.pdf

[12] Desidério R. C. S., and Miyazaki M. C. O. S., Transtorno de Déficit de Atenção / Hiperatividade (TDAH): orientações para a família. Psicol. Esc. Educ. 11 (1), 165-176 (2007). https://doi.org/10.1590/S141385572007000100018.

[13] Cavalcante R. S. C., Colaboração entre pais e escola: educação abrangente. Psicol. Esc. Educ. 2 (2), 153160 (1998). https://doi.org/10.1590/S1413-85571998000200009

[14] Cunha A. E., Afetividade na prática pedagógica: educação, TV e escola. Rio de Janeiro, Brasil: Wak,. 2007.

[15] Rohde L. A., and Halpern, R., Transtorno de déficit de atenção/hiperatividade: atualização. J. Pediatr. (Rio J.). 80 (2 Suppl.), 61-70 (2004). https://doi.org/10.1590/S0021-75572004000300009.

[16] Folquitto C. T. F., Desenvolvimento psicológico e transtorno de déficit de atenção e hiperatividade (TDAH): a construção do pensamento operatório. Ph.D. Thesis Instituto de Psicologia da Universidade de São Paulo - USP, São Paulo, SP. Brasil. Pp. 139 (2009). Retrieved November 18, 2020, from https://www. teses.usp.br/teses/disponiveis/47/47131/tde-21032009 095322/publico/camila_tarif_folquitto.pdf

[17] Bento L A., Ferreira M. A., Santos S. E. L., and Manganotti S. A., Crianças com Transtorno de Déficit de Atenção e Hiperatividade - TDAH: comparação do desempenho escolar dos alunos tratados e não tratados com metilfenidato. Rev. UNINGÁ, 56(2), 151-159 (2019). Retrieved November 18, 2020, from http://revista.uninga.br/index.php/uninga/article/view/779/1975

[18] Araujo M., and Silva S. A. P. S., Comportamentos indicativos do transtorno de déficit de atenção e hiperatividade em crianças: alerta para pais e professores. Rev. PIBIC. 1 (1), 55-64 (2004). Retrieved November 18, 2020, from http://www.unifieo.br/files/0218edfma.pdf

[19] Carlson, E. A., Jacobvitz, D., and Sroufe, L. A., A developmental investigation of inattentiveness and hyperactivity. Child Dev. 66 (1), 37-54 (1995). https://doi.org/10.1111/j.1467-8624.1995.tb00854.x

[20] Vasconcelos M. M., Malheiros A. F. A., Werner Jr. J., Brito A. R., Barbosa J. B., Santos I. S. O., and Lima, D. F. N., Contribuição dos fatores de risco psicossociais para o transtorno de déficit de atenção/hiperatividade. Arq. Neuropsiquiatr. 63 (1), 68-74 (2005). https://dx.doi.org/10.1590/S0004282X2005000100013

[21] Rohde L. A., and Benczik, E. B. P., Transtorno de Déficit de Atenção/Hiperatividade. O que é? Como posso ajudar? Porto Alegre, Brasil: Artes Médicas, 1999.

[22] López Santiago, M. G., El TDAH con relación a la disfunción familiar en adolescentes de secundaria. Ph.D. Thesis Universidad de Ciencias y Artes de Chiapas, Tuxtla Gutiérrez, Chiapas, México, (2020).

[23] Pastura G. M. C., Mattos P., and Araújo A. P. Q. C., Desempenho escolar e transtorno do déficit de atenção e hiperatividade. Arch. Clin. Psychiatry. 32 (6), 324-329 (2005). https://dx.doi.org/10.1590/S0101 $-60832005000600003$

[24] Okuda P. M. M., Lourencetti M. D., Santos L. C. A., Padula N. A. M. R., and Capellini A. S., Coordenação motora fina de escolares com dislexia e transtorno do déficit de atenção e hiperatividade. Rev. CEFAC. 13 (5), 876-885 (2011). https://dx.doi.org/10.1590/S1516-18462011005000048

[25] Barkley, R. A, Attention déficit hyperactivity disorder: a handbook for diagnosis and treatment. New York, USA: The Guilford Press, 2006.

[26] Medina-Papst J., and Marques I. Avaliação do desenvolvimento motor de crianças com dificuldades de aprendizagem. Rev. Bras. Cineantropom. Desempenho Hum. 12 (1), 36-42 (2010). http://dx.doi.org/10.5 007/1980-0037.2010v12n1p36

[27] Fitts P. M., and Posner M. I., Human performance. Belmont: Brooks/Colemann, 1967. 
[28] Miranda M., Rizzutti, S., and Muszkat M., Transtorno do Déficit de Atenção e Hiperatividade. In M. Miranda, M. Muszkat, and C. B. Mello CB, Neuropsicologia do desenvolvimento: Transtornos do neurodesenvolvimento. Rio de Janeiro, Brasil: Rubio, 2013, pp. 31-60.

[29] Barkley R. A, Transtorno de Déficit de Atenção e Hiperatividade: Manual para Diagnóstico e Tratamento, $3^{\mathrm{a}}$ ed. Porto Alegre, Brasil: Artmed, 2008.

[30] Montiel J. M., Bartholomeu D., Armond G. D., Jacini W. F. S., Bueno H. C., Fernandes F., and Cecato J. F., Associações entre medidas de Funções Executivas e sintomas de desatenção e hiperatividade em crianças em idade escolar. Neuropsicol. Latinoam. 6 (1), 13-21 (2014). http://dx.doi.org/10.5579/rnl. 2013.0158

[31] Costa D. S., Medeiros D. G., Alvim-Soares A. M. Jr., Géo L. A. L., and Miranda D. M., Neuropsicologia do transtorno de déficit de atenção/hiperatividades e outros transtornos externalizantes. In D. Fuentes, L. Malloy-Diniz, C. H. P. Camargo, and R. M. Consenza. Neuropsicologia: Teoria e Prática, $2^{\mathrm{a}}$ ed. Porto Alegre, Brasil: Artmed, 2014, pp. 166-182.

[32] Tonelotto J. M. F., and Gonçalves V. M. G., Autopercepção de crianças desatentas no ambiente escolar. Estud. Psicol. (Campinas). 19 (3), 31-41 (2002). https://doi.org/10.1590/S0103-166X2002000300004

[33] Capelatto I. V., Lima R. F., Ciasca S. M., and Salgado-Azoni C. A., Cognitive functions, self-esteem and self-concept of children with attention deficit and hyperactivity disorder. Psicol. Reflex. Crit., 27 (2), 331340 (2014). https://doi.org.10.1590/1678-7153.201427214

[34] Molina M. F., and Maglio A. L., Características del autoconcepto y el ajuste en las autopercepciones de los niños con transtorno por déficit de atención con hiperactividad de Buenos Aires. Cuad. Neuropsicol. 7 (2), 50-71 (2013). Retrieved November 18, 2020, from http://pepsic.bvsalud.org/pdf/cnps/v7n2/n2a04.pdf

[35] Capellini A. S., Ferreira T. L., Salgado C. A., and Ciasca S. M., Desempenho de escolares bons leitores, com dislexia e com transtorno do déficit de atenção e hiperatividade em nomeação automática rápida. Rev Soc Bras Fonoaudiol. 12 (2), 114-119 (2007). https://dx.doi.org/10.1590/S1516-80342007000200008

[36] Farrel M., Dificuldades de relacionamento pessoal, social e emocional: guia do professor. Porto Alegre, Brasil: Artmed, 2008.

[37] Piaget, J., A formação do símbolo da criança, $3^{\text {a }}$ ed. Rio de Janeiro, Brasil: Editora Zahar, 1973.

[38] Américo C. D. P., Kappel N. R. R., and Barzel A., A criança com TDAH: análise do desempenho escolar e engajamento motor. Cinergis, 17 (2), 150-156 (2016). http://dx.doi.org/10.17058/cinergis.v17i2.7747

[39] Barkley R. A, Behavioral inhibition, sustained attention, and executive functions: Constructing a unifying theory of ADHD. Psychol. Bull. 121 (1), 65-94 (1997). https://doi.org.10.1037/0033-2909.121.1.65

[40] Benczik E. B. P., Transtorno do déficit de atenção/hiperatividade: atualização diagnóstica e terapêutica: características, avaliação, diagnóstico e tratamento: um guia para profissionais. São Paulo, Brasil: Casa do Psicólogo, 2000.

[41] Rohde L. A., Barbosa G., Tramontina S., and Polanczyk G., Transtorno de déficit de atenção/Hiperatividade. Rev.Bras. Psiquiatr. 22 (Supl II), 7-11 (2000). https://doi.org/10.1590/S151644462000000600003

[42] Moreira S. C., and Barreto M. A. M., Transtorno de déficit de atenção e hiperatividade: conhecendo para intervir. Rev. Práxis. 1 (2), 65-70 (2009). Retrieved November 18, 2020, from http://revistas.unifoa .edu.br/index.php/praxis/article/view/1123/1013

[43] Santos L. F., and Vasconcelos L. A., Transtorno do Déficit de Atenção e Hiperatividade em Crianças: Uma Revisão Interdisciplinar. Psicol. Teor. Pesqui. 26 (4), 717-724 (2010). Retrieved November 18, 2020, from https://www.scielo.br/pdf/ptp/v26n4/15.pdf

[44] Cypel S., A criança com déficit de atenção e hiperatividade: atualização para pais, professores $e$ profissionais da saúde. São Paulo, Brasil: Lemos, 2000.

[45] Rubio-Grilo M. H., Salazar-Torres L. J., and Rojas-Fajardo A., Habilidades motoras y de procedimiento que interfieren en la vida académica habitual de un grupo de Estudiantes con signos y síntomas de TDAH. Rev. Colomb. Psiquiatr. 43 (1), 18-24 (2014). https://doi.org/10.1016/S0034-7450(14)70038-1

[46] Rocha M. M., and Ferreira M. C B., Autopercepção de um grupo de crianças com diagnóstico de TDAH: implicações educacionais. Rev. FAED. 30 (2), 171-191 (2018). Retrieved November 18, 2020, from https://periodicos.unemat.br/index.php/ppgedu/article/view/3883/3078

[47] Martinelli S. C., and Genari C. H. M., Relações entre desempenho escolar e orientações motivacionais. Estud. Psicol. (Natal). 14 (1), 13-21 (2009). http://dx.doi.org/10.1590/S1413-294X2009000100003

[48] Paiva M. L. M. F., and Boruchovitch E., Orientações motivacionais, crenças educacionais e desempenho escolar de estudantes do ensino fundamental. Psicol. Estud. 15 (2), 381-389 (2010). http://dx.doi.org/10. 1590/S1413-73722010000200017

[49] Martinelli S. C., Um estudo sobre desempenho escolar e motivação de crianças. Educar Rev. (53), 201-216 (2014). http://dx.doi.org/10.1590/0104-4060.27122 
[50] Fonseca M. F. B. C., Muszkat M., and Rizzutti S. Transtorno do déficit de atenção e hiperatividade na escola: mediação psicopedagógica. Rev. Psicopedagia. 29 (90), 330-339, (2012). Retrieved November 18, 2020, from http://pepsic.bvsalud.org/pdf/psicoped/v29n90/07.pdf

[51] Moura L. T., Silva K. P. M., and Silva K. P. M., Alunos com TDAH (Transtorno de Déficit de Atenção e Hiperatividade): um desafio na sala de aula. Rev. Eletrônica Acervo Saúde. (22), e611 (2019). https://doi.org/10.25248/reas.e611.2019

\section{AUTHOR'S BIOGRAPHY}

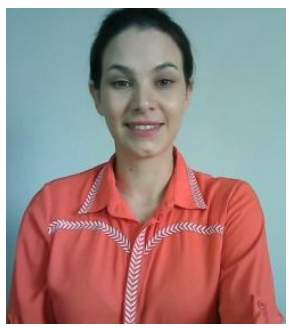

Elizane Franchi Pelligrini, Graduated in Pedagogy from the Lutheran University of Brazil (2007). Specialist in Clinical and Institutional Psychopedagogy from the Medical School of São José do Rio Preto (2013). Master of Science in Education from Unigran (2019). Currently is a Psychopedagogue at the Marapoama City Hall. Works in the area of Education as a literacy teacher, family counselor and psychopedagogical assistance with students diagnosed with ADHD.

Citation: Elizane Franchi Pelligrini, et.al. "Between the Frontier of Learning and School Failure in Attention Deficit Hyperactivity Disorder" International Journal of Humanities Social Sciences and Education (IJHSSE), vol 7, no. 12, 2020, pp. 01-14. doi: https://doi.org/10.20431/2349-0381.0712001.

Copyright: (C) 2020 Authors. This is an open-access article distributed under the terms of the Creative Commons Attribution License, which permits unrestricted use, distribution, and reproduction in any medium, provided the original author and source are credited. 